\title{
Assessment of clinical and laboratorial parameters and the usefulness of the Brain Natiuretic Peptide as a predictor for successful extubation in the ICU
}

\author{
Avaliação de fatores clínicos, laboratoriais e da utilidade do Peptídeo \\ Natriurético Cerebral como preditivos do sucesso da extubação em UTI \\ Maria Aparecida Vitagliano Martins ${ }^{1}$ (D), Silene El-Fakhouri ${ }^{1}$ (D), Luciene de Oliveira Conterno ${ }^{2}$ (D), \\ Thie Uehara Sampaio ${ }^{1}$ (i)
}

\begin{abstract}
Introduction: Identification of predictors for successful extubation in an Intensive Care Unity and use of Brain Natriuretic Peptides (BNP) in predicting mechanical ventilation weaning and extubation outcome.

Aims: Evaluation of the effect of variables such as patient's age, severity score, use of sedation, use of vasoactive drugs, hydric balance, blood gas data, days under mechanical ventilation, the occurrence of adverse events and plasma BNP levels on the success of extubation.

Method: A prospective cohort study of adult patients admitted to a 12- bed-general ICU, from April $1^{\text {st }} 2016$ to August $10^{\text {th }}$ 2017, under mechanical ventilation for $>24 \mathrm{~h}$, accompanied until discharge or death. Clinical variables were analyzed and BNP was assessed before initiation of Spontaneous Breathing Trial (SBT) and then again before extubation. Statistical Analysis: a descriptive and comparative data analysis, univariate and logistic regression analysis for verification of variables independently related to successful extubation $(p<0.05)$.

Results: Study of 105 patients, mean age of $53.9 \pm 19.8$ years, $81 \%$ of success in extubation; the overall mortality rate of $11.4 \%$; variables associated to successful extubation: age, APACHE II, SAPS II, days of hospitalization before ICU admittance, days under mechanical ventilation, days of stay in ICU and occurrence of nosocomial infection ( $p<0.05)$; BNP levels were lower in patients with successful extubation although not statistically significant; multivariate analysis showed that patient's age and days of hospitalization before ICU admittance were each independently linked to extubation failure; APACHE II score and days of hospitalization before ICU admittance were each independently associated to risk of death.

Conclusion: Despite being older and with higher severity scores, patients had a higher success rate in extubation than found in similar studies. However, the mortality rate in cases of failed extubation was higher. Data obtained was in agreement to studies that suggested that patient's age, severity score, days of hospitalization before ICU admittance, days of stay in ICU, days under MV and infection occurrence were all variables associated as much extubation failure as to risk of death. A direct association between BNP levels and successful extubation and the usefulness of assessing BNP in the conduction of WMV was not confirmed.
\end{abstract}

Keywords: Ventilator weaning, Airway extubation, Brain natriuretic peptide, Intensive care unit, Death rate.

\section{RESUMO}

Introdução: Identificação de fatores preditivos do sucesso da extubação em Unidade de Terapia Intensiva e uso do Peptídeo Natriurético Cerebral (BNP) como preditor do sucesso do desmame da ventilação mecânica e extubação. Objetivo: Avaliação do efeito de variáveis como idade, escores de gravidade, uso de sedação, uso de drogas vasoativas, balanço hídrico, gasometria, dias sob ventilação mecânica, ocorrência de eventos adversos e níveis plasmáticos de BNP no sucesso da extubação .

Método: Estudo de coorte prospectivo de pacientes adultos internados em UTI geral com 12 leitos, de 10 de abril de 2016 a 10 de agosto de 2017, sob ventilação mecânica (VM) por > 24 horas, acompanhados até a alta ou óbito. Variáveis clínicas foram analisadas e o BNP dosado antes do início do Teste de Respiração Espontânea (TRE) e, no-

Faculdade de Medicina de Marília. Hospital de Clinicas, Marília, São Paulo, (SP), Brazil.

Universidade Estadual de Campinas. Faculdade de Medicina da Campinas, São Paulo, (SP), Brazil 
vamente, antes da extubação. Análise estatística: análise descritiva e comparativa dos dados, análise univariada e regressão logística para verificação de variáveis independentemente relacionadas ao sucesso da extubação ( $p<0,05)$. Resultados: Avaliados 105 pacientes, idade média 53,9 $\pm 19,8$ anos, sucesso na extubação de $81 \%$; taxa de mortalidade geral de 11,4\%; variáveis associadas ao sucesso da extubação: idade, APACHE II, SAPS II, dias de internação antes da admissão na UTI, dias em ventilação mecânica, dias de permanência na UTI e ocorrência de infecção hospitalar ( $p<0,05$ ); os níveis de BNP foram mais baixos em pacientes com sucesso da extubação, embora não estatisticamente significativos; a análise multivariada mostrou que as variáveis, idade e dias de internação, antes da admissão na UTI, estavam, independentemente, ligadas ao fracasso da extubação; as variáveis APACHE II e dias de internação antes da admissão na UTI estavam, independentemente, associados ao risco de morte.

Conclusão: Apesar de mais velhos e com escores de gravidade mais elevados, nossos pacientes apresentaram maior taxa de sucesso na extubação quando comparados a estudos semelhantes. No entanto, a taxa de mortalidade em casos de falha da extubação foi maior. Os dados obtidos estão de acordo com estudos que sugerem que variáveis como idade, escores de gravidade, dias de internação antes da admissão na UTI, dias de permanência na UTI, dias em VM e ocorrência de infecção estão associadas tanto ao fracasso de extubação quanto ao risco de morte. Não foi possível confirmar a associação direta entre os níveis plasmáticos de BNP e o sucesso da extubação, assim como sua utilidade na condução do desmame da ventilação mecânica.

Palavras-chave: Desmame da Ventilação Mecânica, Extubação das vias aéreas, Peptídeo natriurético cerebral, Unidade de Tratamento Intensivo, Taxa de mortalidade.

\section{INTRODUCTION}

The death rate in patients admitted to Intensive Care Units (ICUs) is related to each patient's characteristics, the severity of the initial disease, submission of the patient to invasive procedures and the occurrence of adverse events $^{(1)}$. Patients submitted to long term mechanical ventilation (MV) present poor prognosis due to a high number of complications, increased ICU and hospital mortality rates and longer hospital stay, all of which cause great loss of human and financial resources ${ }^{(2)}$. As noted by the 2013 Brazilian Recommendations for Mechanical Ventilation (BRMV 2013)(3), treatment outcome in patients with respiratory failure has shown much better results in the last few decades, although recent data has shown that death rates in our mechanically ventilated patients are higher than found in developed countries ${ }^{(4,5,6)}$.

After the cause of respiratory insufficiency is resolved comes the challenge of weaning the patient from mechanical ventilation (WMV) followed by extubation. Even when considering the current procedure for WMV, which is standardized, the average rate of failure is $30 \%$, with the Spontaneous Breathing Trial (SBT) considered to be the most accurate indicator for a successful WMV. However, even in patients with successful SBT, the extubation failure rate is still high (15$20 \%)^{(5)}$. Failure of SBT and extubation is associa- ted with a $43 \%$ mortality rate, with a $12 \%$ mortality rate in patients with successful extubation. A definitive predictor for WMV results in patients submitted to $M V$ is not yet known(6).

The incidence of respiratory insufficiency increases almost exponentially with patients age, presenting up to three times more in patients 65 and older than in patients 55 years old or youn$\operatorname{ger}^{(7)}$. According to Silva et al(8), patients older than 65 with organ failure present an additional $20 \%$ increase in mortality during the hospital stay. Older patients also present much worse evolution under $M V$, a higher rate of extubation failure, and a higher death rate due to their respiratory problems.

Some studies indicate that WMV can be optimized by lessening pulmonary capillary pressure with strict control of the patient's hydric balance (HB) during the weaning process, and that atrial natriuretic peptides levels (BNPs), considered as being markers for cardiac insufficiency, could be useful as predictors of WMV result ${ }^{(9,10,11)}$. Mekontso-Dessap et $\mathrm{al}^{(10)}$ conducted the first study of managing $\mathrm{HB}$ by assessing ANP levels during WMV. The authors found an association between successful WMV and increased use of diuretics, a lower $\mathrm{HB}$ and a shorter period of MV, with no increase in adverse effects, especially in patients presenting with left ventricular dysfunction. In this study, baseline BNP levels were moderately elevated 
exclusively in those patients where SBT was unsuccessful because of cardiac dysfunction.

The success rate of WMV was as high as $97 \%$ when BNP was assessed in SBT. When WMV was undertaken based only on the patient's SBT results, the success rate was as low as $80 \%$. Thus, assessment of natriuretic peptide levels could help identify the best time for weaning a patient of $M V^{(9,11)}$.

The present study aimed to identify factors that were predictive of WMV results in adult patients admitted to a general ICU. Specific goals were: to determine the success rate of WMV in patients under MV for more than 24 hours; to assess the impact of epidemiological, clinical and laboratory variables in WMV outcome; to determine specifically if BNP levels before SBT and prior to extubation could accurately predict success or failure of extubation.

\section{METHOD}

\section{Studied population}

A prospective cohort study was conducted at the Hospital de Clínicas da Faculdade de Medicina de Marília, São Paulo state, Brazil, in the high to medium complexity Intensive Care Unit B. This unit has 12 beds and admits patients in need of intensive care after medical or surgical treatment, apart from cardiac surgery patients and organ transplanted patients.

The study was evaluated and approved by the hospital's Ethics Committee and included 193 patients staying in the ICU during the period from April $1^{\text {st }} 2016$ to August $10^{\text {th }} 2017$, who were $\geq$ 18 years old, received MV for $\geq 24 \mathrm{~h}$, and were observed continuously until discharge or death. Patients were included when they developed respiratory insufficiency and were then intubated in the ICU, or when already intubated, transferred to the ICU from the OR, infirmary, or the ER. The cause of intubation for each patient was registered in standard medical files and was related to the patient's pathology, clinical, surgical and/ or due to trauma. The need for intubation of ICU patients was determined according to criteria established in BRMV 2013(3).

\section{Data collection}

Three researchers collected data from the patients after they signed standard terms of consent, while statistical analysis was done by a fourth. Only one patient, legally represented by family members who did not authorize his participation, was excluded from the study. For patients who required multiple periods of intubation, only the first of these was considered. All patients that were readmitted to the ICU up to seven days after discharge and required intubation and MV for more than 24 hours, were included as a new case. Those readmitted up to 48 hours after extubation and discharge were considered as failed cases. Criteria for exclusion from the study: patients or their legal guardians who declined to participate in the study.

All data used in the study was collected from standard medical files. These files contained information regarding the patient's origin, cause of admittance to the hospital, comorbidities, severity score and organ dysfunction (APACHE II, SAPS II and SOFA) ${ }^{(12,13,14)}$. Variables such as age, the period of days under MV and under sedation, use of vasopressors, hydric balance, hypercapnia, the occurrence of adverse effects (infection, venous thromboembolism, digestive bleeding and onset of pressure ulcers) were noted and the patients had BNP levels assessed at two moments: immediately before initiating SBT and immediately before extubation.

All patients were evaluated daily and, in accordance to BRMV 2013(3), were considered apt for SBT when the following accumulated criteria was observed: $\mathrm{PaO} 2 \geq 60 \mathrm{mmHg}$ with FIO2 $\leq 0,4$ and PEEP $\leq 5$ at $8 \mathrm{cmH} 20$; presenting stable hemodynamics with good tissue perfusion when using a low dosage or no use of vasopressors; absence of coronary insufficiency or arrhythmia with hemodynamic repercussions; cause of respiratory failure resolved or controlled; patient capable of initiating respiratory effort; hydric balance lower or equal to zero in the last 24 hours, and normal acid-base and hydroelectrolytic balances. Patients normally did not receive noninvasive ventilation following extubation.

A continuous T-tube ( $T$ ) was used for 30 to 120 minutes during SBT of the patients, and was observed for indications of success or failure in the test. Patients who were able to maintain a stable 
respiratory pattern, good level of gas exchange, hemodynamic stability and were adequately comfortable for a minimum of 30 minutes, were then extubated and were considered as successful in SBT. SBT was considered failed and was then interrupted when the patient presented one or more of the following symptoms: respiratory rate higher than 35 breaths per minute, arterial oxygen saturation lower than 90\%, heart rate (HR) higher than 140 beats per minute, systolic arterial pressure higher than $180 \mathrm{mmHg}$ or lower than $90 \mathrm{mmHg}$; signs and symptoms related to agitation, sudoresis and/or change in the level of consciousness ${ }^{(3)}$. All patients with successful SBT were extubated without the use of any other predictive indicators.

After extubation, all patients who presented signs of respiratory discomfort, desaturation and/or hemodynamic instability were reintubated and were considered failed extubation cases. Similarly, patients submitted to tracheostomy after unsuccessful WMV, no matter how many times weaning or extubation was attempted, were considered failed cases.

The concept "success of weaning" refers to the patients who underwent SBT successfully while still connected to the ventilator. The term "success of extubation" was used about those patients where the endotracheal prosthetic device was withdrawn (extubation) after a successful result of SBT and the patient did not require reintubation for at least 48 hours afterward(3). However, the present study considered WMV not completely successful when the patient had to be reintubated up to 48 hours after a successful SBT and extubation.

\section{Sample collection and BNP assessment}

Blood samples for assessment of BNP were collected in tubes containing clot activator gel and then sent to the laboratory (Faculdade de Medicina de Marília - SP blood center) and were processed by an ARCHITECT i1000SR device, being submitted to an ARCHITECT BNP test which consists of a chemiluminescent microparticle assay (CMA) for measurement of type $B$ natriuretic peptide (BNP) levels in human plasma ${ }^{(15)}$. Normal BNP values were considered according to age: $<125 \mathrm{pg} / \mathrm{ml}$ (picograms per milliliter) for patients $\leq 75$ years of age and < $450 \mathrm{pg} / \mathrm{ml}$ for patients $\geq 76$ years old ${ }^{(15)}$.

\section{Data analysis}

A descriptive data analysis was performed after verifying data normality using a statistical analysis suitable to the sample size and mean values for the continuous variables and proportions of the categorical variables. The continuous variables were compared by Student's t-test, or ANOVA, when comparing two or more mean values, and the categorical variables were compared by the chi-square test or by Fisher's exact test, according to the nature of the data. Microsoft Excel (Microsoft, EUA) was used to create a data bank and statistical analysis was done using Statistical Package for Social Sciences (SPSS), version 17 (SPSS Inc., EUA). Statistical significance was considered at $p<0.05$.

Clinical and laboratory parameters of patients with successful extubation were compared to those with extubation failure using logistic regression analysis to individually assess which factors were linked to success or failure of extubation. A backward conditional method was used for this, using a model that included all variables identified in the univariate analysis as being linked to the outcome of the extubation.

\section{Results}

Initially, 193 patients admitted to ICU B of the Hospital de Clínicas de Marília - SP under MV for more than twenty-four (24) hours, from April $1^{\text {st }}, 2016$, to August $10^{\text {th }} 2017$ were included in the study. SBT was performed in 133 (68.9\%) patients. Of the 60 patients not submitted to SBT, $53(27.5 \%)$ did not present the necessary criteria for the trial and $7(3,6 \%)$ were not monitored (accidental extubation). Figure 1

\section{Spontaneous breathing trial, BNP assess- ment and Extubation}

After resolution of cause for MV, 133 (68.9\%) patients were submitted to SBT, $90(67.7 \%)$ were successfully extubated and $43(32.3 \%)$ underwent failed extubation. Of the 133 patients, 105 were submitted to SBT and two assessments of BNP. 85 of these 105 ( $81 \%$ ) patients were extubated successfully and 20 (19\%) failed. Figure 1 
Figure 1 - Flow chart of extubation failure or success

$$
\begin{gathered}
\text { Patient Total } \\
\text { MV }>24 h \\
n=193
\end{gathered}
$$

NO SBT $\mathrm{n}=60(31.1 \%)$

Not clinically able $\mathrm{n}=53$

Accidental extubation $\mathrm{n}=7$

$$
\mathrm{n}=133(68.9 \%)
$$
Patients submitted only to SBT $\mathrm{n}=28$

\section{Extubation Failure $\mathrm{n}=20(19 \%)$}

MV: Mechanical Ventilation; SBT: Spontaneous Breathing Trial; BNP: Brain Natriuretic Peptides, pg/ml

Epidemiological and clinical parameters of the 105 patients submitted to SBT and two BNP assessments are indicated in Table 1.

Table 1. Epidemiological and clinical parameters

\begin{tabular}{lc}
\hline & $\mathrm{n}=105$ \\
\hline Male, $\mathrm{n}(\%)$ & $59(56.2)$ \\
Age, years & $53.9 \pm 19.8$ \\
Associated disease*, $\mathrm{n}(\%)$ & $8(7.6)$ \\
$\quad$ Dyslipidemia & $9(8.6)$ \\
Depression & $10(9.5)$ \\
Drug addiction & $14(13.3)$ \\
Chronic Obstructive Pulmonary Disease & $16(15.2)$ \\
Cardiac Insufficiency/AMI & $22(21.0)$ \\
Diabetes Mellitus & $36(34,2)$ \\
Alcohol consumption/Tabaccoism & $37(35.2)$
\end{tabular}

Successful

Extubation

$\mathrm{n}=85(81 \%)$

(continua...) 
Table 1

(continuação)

\begin{tabular}{lc}
\hline & $\mathrm{n}=105$ \\
\hline Neoplasia, $\mathrm{n}(\%)$ & $21(20.0)$ \\
Neurologic disease, $\mathrm{n}(\%)$ & $34(32.4)$ \\
DPOC, $\mathrm{n}(\%)$ & $15(14.3)$ \\
Type of admission, $\mathrm{n}(\%)$ & $16(15.2)$ \\
$\quad$ Trauma & $43(40.9)$ \\
$\quad$ Elective or emergency surgery & $46(43.9)$ \\
$\quad$ Internal medicine & $7.5 \pm 12.9$ \\
Days of hospitalization before admittance to ICU & $13.7 \pm 11.0$ \\
Days of MV & $85(81)$ \\
Success of extubation, $\mathrm{n}(\%)$ & $14(13.3)$ \\
Tracheostomy, $\mathrm{n}(\%)$ & $12(11.4)$ \\
Death, $\mathrm{n}(\%)$ & \\
\hline
\end{tabular}

Data are presented as mean values \pm SD (Standard Deviation) unless otherwise indicated. Percentage sum may not attain $100 \%$ due to rounding of numbers; *Patients may have more than one underlying disease as the cause for admittance to ICU; ICU: Intensive care Unit; AMI: Acute Myocardial Infarction. MV: Mechanical Ventilation; COPD: Chronic Obstructive Pulmonary Disease.

All patients successfully extubated were younger $(p=0.001)$, presented lower Apache II and SAPS II $(p=0.03$ and $p=0.03)$ severity scores, had lower rates of hospital-acquired infections $(p=0.031)$, had fewer average days of hospital stay prior to admittance to ICU $(p=0.046)$, of stay in ICU $(p=0.001)$, and under mechanical ventilation $(p<0.001)$. No statistical difference was found between both groups in terms of mean FiO2 (Fraction of inspired oxygen), $\mathrm{PaO} 2$ (Arterial partial oxygen pressure), PCO2 (Carbon dioxide partial pressure) and arterial bicarbonate values, all of which assessed prior to SBT (Table 2).

Table 2. Success and failure of extubation $(n=105)$

\begin{tabular}{lccc}
\hline & Success $(\mathrm{n}=85)$ & Failure $(\mathrm{n}=20)$ & $P$ value \\
\hline Age, years & $50.8 \pm 19.6$ & $66.7 \pm 15.5$ & 0.001 \\
Male, $\mathrm{n}(\%)$ & $48(56.5)$ & $11(55)$ & 1.000 \\
APACHE II & $22.1 \pm 8.7$ & $26.9 \pm 9.0$ & 0.03 \\
SAPS II & $54.0 \pm 14.6$ & $62.1 \pm 15.9$ & 0.03 \\
Days of hospitalization before admittance to ICU & $5.9 \pm 11.8$ & $14.9 \pm 16.1$ & 0.046 \\
Days of stay in UTI & $15.1 \pm 8.9$ & $28.3 \pm 14.0$ & 0.001 \\
Days under VM & $10.8 \pm 8.2$ & $25.8 \pm 13.4$ & $<0.001$ \\
FiO2 (\%) & $35.1 \pm 7.3$ & $35.0 \pm 5.6$ & 0.937 \\
PaO2 (mmHg) & $122.7 \pm 46.8$ & $113.0 \pm 25.3$ & 0.472 \\
PCO2 (mmHg) & $41.4 \pm 7.6$ & $41.2 \pm 7.5$ & 0.923 \\
Arterial bicarbonate, mEq/L & $25.8 \pm 3.6$ & $27.5 \pm 4.1$ & 0.067 \\
Positive hydric balance, milliliters & $2525 \pm 1669$ & $1975 \pm 1527$ & 0.282 \\
Negative hydric balance, milliliters & $1455 \pm 1122$ & $2099 \pm 2467$ & 0.467 \\
Use of vasoactive drugs, $\mathrm{n}(\%)$ & $20(23.5)$ & $4(20)$ & 1.000
\end{tabular}

(continua...) 
Table 2

(continuação)

\begin{tabular}{lccc}
\hline & Success $(\mathrm{n}=85)$ & Failure $(\mathrm{n}=20)$ & $P$ value \\
\hline Neurological Disease, $\mathrm{n}(\%)$ & $29(34.1)$ & $5(25)$ & 0.433 \\
COPD, $\mathrm{n}(\%)$ & $10(11.8)$ & $5(25)$ & 0.156 \\
Hospital-acquired infection, $\mathrm{n}(\%)$ & $41(48.2)$ & $15(75)$ & 0.031 \\
Death, $\mathrm{n}(\%)$ & $3(3.5)$ & $9(45)$ & $<0.001$ \\
\hline
\end{tabular}

Data are presented as mean values \pm SD (Standard Deviation) unless otherwise indicated. Percentage sum may not attain $100 \%$ due to rounding of numbers; ICU: Intensive care Unit; SBT: Spontaneous Breathing Trial; APACHE II - Acute Physiology and Chronic Health Enquiry; SAPS II - Simplified Acute Physiology Score; MV: Mechanical ventilation; FiO2: Fraction of inspired oxygen; PaO 2: Arterial partial oxygen pressure; PCO2: carbon dioxide partial pressure; mEq/L: milliequivalents/Liter; COPD: Chronic Pulmonary Obstructive Disease.

The comparison of variables in cases of successful and failure extubation that were found as not statistically significant to the outcome was the use of vasoactive drugs (VAD), presence of neurological disease and/or chronic pulmonary obstructive disease, and a positive or negative hydric balance (mean values for last 48 hours prior to extubation). General mortality rate was $11.4 \%$ (12), 3.5\% (3) in successfully extubated patients and $45 \%$ (9) in those with failed extubation $(p=<0.001)$. Table 2
Mean BNP levels assessed immediately prior to initiation of SBT and before extubation were both lower in the patients who were successfully extubated, although the difference was not statistically significant $(p=0.294$ and $p=0.278)$; average difference between BNP levels, assessed before the start of SBT and then before extubation, was also lower in patients successfully extubated $(p=0.233)$, as was the percentual change of BNP values $(p=0.492)$, although both were statistically insignificant (Table 3 ).

Table 3. Success and failure of extubation $(n=105)$

\begin{tabular}{lccc}
\hline & Success $(\mathrm{n}=85)$ & Failure $(\mathrm{n}=20)$ & $P$ value \\
\hline BNP PRIOR to SBT, pg/ml & $248,9 \pm 448,5$ & $453,7 \pm 823,4$ & 0,294 \\
BNP PRIOR to Extubation, $\mathrm{pg} / \mathrm{ml}$ & $257,4 \pm 468,2$ & $458,5 \pm 775,0$ & 0,278 \\
$\neq$ BNP & $38,4 \pm 53,2$ & $64,6 \pm 80,6$ & 0,233 \\
$\Delta \%$ BNP & $11,3 \pm 8,1$ & $18,5 \pm 18,0$ & 0,492
\end{tabular}

Data are presented as mean values \pm SD (Standard Deviation) unless otherwise indicated. SBT: Spontaneous Breathing Trial; BNP: Brain Natriuretic Peptide; pg/ml: picograms/milliliter;

\# BNP: difference between two BNP assessments; $\Delta \%$ : percentage of change between both BNP assessments.

The multivariate analysis by logistic regression found that patient's age and the average period of hospitalization before transference to ICU were both independently associated with extuba- tion failure. The patient's APACHE score and average period in the hospital before transference to ICU were variables independently associated with the death of the patient (Table 4).

Table 4 - Extubation failure and death of patient in the logistic regression analysis

\begin{tabular}{lccc}
\hline & OR & $95 \%$ CI & p \\
\hline Unsuccessful extubation & & $1.01-1.12$ & 0.001 \\
Age & 1.06 & $1.01-1.12$ & 0.046 \\
$\begin{array}{l}\text { Days of hospitalization before ICU } \\
\text { Death of patient }\end{array}$ & 1.07 & $1.02-1.22$ & 0.03 \\
APACHE & 1.11 & $1.01-1.13$ & 0.046 \\
Days of hospitalization before ICU & 1.07 & & \\
\hline
\end{tabular}

OR: Odds Ratio; Cl: Confidence interval 


\section{DISCUSSION}

The 105 patients admitted to ICU B of the Hospital de Clínicas de Marília that were under MV for more than 24 hours, were submitted to SBT and had their BNP levels assessed in two different moments, presented the following epidemiological profile: the average age of $53.9 \pm 19.8$ years, predominantly male, submitted mainly to clinical treatment. The most common cause for admittance to ICU was a respiratory related disease, external cause, arterial hypertension, and diabetes mellitus. All these findings were similar to those of other national and international studies, except for the average age of patients, which were younger in the present study $(5,6,16,17)$.

Compared to patients in national and international studies, patients in the present study were younger and had higher mean severity score values ${ }^{(5,6,18)}$. In a national multicentric study ${ }^{(18)}$, the average prognostic APACHE $\mathrm{II}^{(12)}$ score assessed upon ICU admittance was $19.4 \pm 8.3$, lower than that found in the present study. This indicates a more severe state of our patients when admitted to the ICU.

The average period of days under MV of our patients was higher than that reported in similar studies, which indicate an average of 5 to 7.7 days ${ }^{(5,6)}$. The difference between this period in the present study and a national multicentric study could be related to the populations considered in each. Our study considered all patients under MV for more than 24 hours. The multicentric study excluded patients whose clinical characteristics would probably lead to difficulties in WMV (readmitted patients, moribund and pregnant patients, and those with abstinence syndrome). Also, our patients were submitted mainly to medical treatment while, according to Franca et al. (19) in a prospective cohort study conducted in 12 ICU wards of the $\mathrm{HC}$ da Faculdade de Medicina da Universidade de São Paulo, hospitalization of patients undergoing surgical treatment seems to have a protective effect, and was associated to a shorter period under MV and lower death rates in patients staying in the hospital and the ICU.

The success rate of extubation for the 105 patients submitted to an SBT and two BNP assessments was $81 \%$, higher than the $54 \%$ success rate reported in the national multicentric stu$d y^{(5)}$, and the $53.3 \%$ and $62.5 \%$ success rate in two other international studies ${ }^{(20,21)}$. On the other hand, $19 \%$ of the patients in the present study required tracheal reintubation and were considered failed extubation cases, which was compatible with numbers seen in other national and international studies that reported a 6.1 to $28 \%$ rate of patient reintubation $(5,6,21,22,23)$.

The present study investigated the variables that were found to be associated with WMV and if the BNP levels from two different moments, before initiating SBT and prior to extubation, could accurately predict the extubation success or failure.

Variables associated with extubation failure were: APACHE II and SAPS II scores, number of days of hospitalization prior to ICU admittance, number of days in the ICU, number of days under MV and occurrence of hospital-acquired infections. According to Freitas et al(24) an APACHE II score of $<16$ and a period of $<8$ days under MV were the conditions found to be statistically significant to successful extubation by a logistic regression analysis to assess the simultaneous influence of medical and mechanical factors in result of WMV.

All successfully extubated patients were admitted to the ICU earlier than those with failed extubation. According to Franca et al (19), a wait of more than 4 days for an opening in an ICU is a factor for the risk of death in patients suffering from respiratory insufficiency.

The difference between positive and/or negative absolute $\mathrm{HB}$ values in the 48 hours before extubation from successful and from failed extubation cases was not statistically significant. Zapata et $\mathrm{al}^{(25)}$ found consistently positive HB values in patients that would then fail SBT, especially those with cardiac insufficiency. However, a patient's HB value alone was not accurate in predicting failure of SBT and the patient's last 48-hour HB values were not associated with their SBT result.

Antônio et al(26) did a prospective study of patients submitted to MV and found no association between the patient's last 48-hour HB values and the result of their SBT, except for patients with chronic pulmonary obstructive disease (CPOD). 
These patients showed lower positive HB values than other patients, probably due to interaction between pulmonary and cardiac physiology, which seemed to have a positive effect on the result of their SBT. Although WMV failure and a positive HB were found to be associated, cause and effect were not clear. In any case, it remains to be seen If $\mathrm{HB}$ values alone actually interfere with the patient's improvement, or if it is merely a confusing factor, related to disease severity.

BNPs are sensitive markers of myocardial damage, and fluctuation of BNP serum levels during SBT has been regarded as a predictor for WMV outcome. Variation in post-loading of the left ventricle, with subsequent subclinical pulmonary congestion or outright pulmonary edema, is common during SBT and the fluctuation of BNP blood levels, which have an estimated 20 minute half-life, can be useful for detecting this occurrence $^{(27)}$.

In our study, all patients extubated successfully presented a lower rise in BNP plasma levels than those with failed extubation. Similarly, the absolute difference and the percentage variation were both lower in patients successfully extubated compared to those where the process was failed. However, although both absolute and relative BNP values were different, these were not statistically significant according to the univariate and the multivariate analysis.

The only association between BNP and outcome of WMV found by Mekontso-Dessap et al(28) was an elevated basal BNP level in patients with unsuccessful WMV and, according to Farghaly et $\mathrm{al}^{(20)}$, the absence of association between blood BNP levels during SBT and the success of extubation found by those authors is related to the duration of SBT. Mekontso-Dessap et al(28) collected two different samples spaced apart by only 01 hour. According to Farghaly et al ${ }^{(20)}$, ideally a second blood sample should be collected 02 hours after initiation of SBT, a strategy which they consider responsible for their results. These authors found a positive association between changes in BNP levels ( $\triangle \% B N P)$ and the success of extubation.

Still, according to Farghaly et al(20), when compared to other parameters such as Rapid Shallow Breathing (RSBI) and Minute Volume lower than 10 liters/minute, a $\Delta \% B N P \leq 14.9$ with the collection of second sample 2 hours into the SBT presents better sensibility, specificity and positive and negative predictive value (respectively $81.25 \%, 65 \%, 65 \%$ and $70 \%$ ).

The present study contradicts those from many studies $(9,10,11,20,21,25,27,28)$ in which an association between BNP levels and the result of patient's SBT was found. This could be related to the duration of SBT. An SBT performed in less than 2 hours would not trigger a cardiac overload that would release a level of BNPs that could identify patients who will probably undergo failed extubation $(11,20,21,28,29)$. Based on each patient's condition and response, as indicated in BRMV 2013(3), the duration of SBT in the present study varied from 30 to 120 minutes. This could have interfered with our results since according to Maraghi et $\mathrm{al}^{(21)}$, the duration of SBT has a great influence on BNP levels. Because of BNP half-life, plasma levels would only begin to rise after about 2 hours, a longer period than considered in our study.

In our study, BNP percentage variation was lower in successfully extubated patients. These values were close to the cut-off indicated by Maraghi et $\mathrm{al}^{(21)}$ and inside the range found in a systematic study review ${ }^{(27)}$.

A recent meta-analysis and systematic review ${ }^{(27)}$ showed that relative BNP variation during SBT, $\triangle \% B N P$, seems to be a valuable predictor for successful extubation following a successful SBT. However, a specific limit could not be calculated or validated by the meta-analysis. On the other hand, many studies reported a $\triangle \% B N P$ of 13 to $20 \%$. Their results were not enough to define the use of only $\triangle \% B N P$, not associated with conventional SBT, as a predictor of extubation outcome. Similarly, assessment of $\triangle B N P$, of BNP levels before and of BNP levels after SBT, could not be considered alternative or contributing indicators of SBT efficacy for predicting successful extubation due to insufficient data. The authors suggest the need for a deeper investigation of the use of $\triangle \% B N P$ as an alternative or contributing tool to $\mathrm{SBT}$, and the prospective validation of specific limits, which would be done in the following stage of their study.

In the present study, patients with extubation failure presented much higher, although 
not statistically significant, BNP levels during SBT, which were also found in many similar stu$\operatorname{dies}^{(5,10,20,21,25,27,28,29)}$. Although these studies indicate a direct association between elevated BNP levels during SBT and extubation failure, our data could not confirm any association between BNP levels and extubation outcome.

In the conduction of the present study several limitations were identified, including the small number of patients submitted to SBT and two BNP assessments. Another was the absence of classification of pulmonary compromise in the patients, with the exclusion of patients with higher severity and more comprised lungs. Ac-

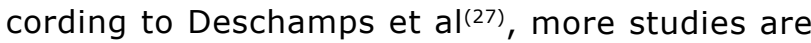
needed to define BNP as a predictor of extubation outcome.

\section{CONCLUSION}

Although older and with higher severity scores, patients in the present study presented a higher rate of successful extubation than reported in similar studies. On the other hand, the mortality rate of our patients with extubation failure was higher.

Our data is in accordance with reports from studies that suggest that patient's age, severity score, length of hospital stay before ICU admittance, length of ICU stay, days under MV and infection occurrence were all variables associated with as much extubation failure as to the risk of death.

A direct association between BNP levels and successful extubation and the usefulness of assessing BNP in the conduction of WMV was not confirmed.

\section{REFERENCES}

1. Moraes RS, Fonseca JM, di Leoni CB. ICU mortality, associated factors and assessment of functional status after hospital discharge. Rev Bras Ter Intens, $2005 ; 17(2): 80-4$.

2. Loss SH, Oliveira RP, Maccari JG, Savi A, Boniatti MM, Hetzel MP, Dallegrave DM, Balzano PC, Oliveira ES, Höher JA, Torelly AP, Teixeira C. The reality of patients requiring prolonged mechanical ventilation: a multicenter study. Rev Bras Ter Intensiva. 2015; 27(1):26-35.
3. Barbas $C S$, Isola $A M$, Farias $A M$, Cavalcanti $A B$, Duarte $A C$ et al. Brazilian recommendations of mechanical ventilation 2013. Partes 1 e 2 . Rev Bras Ter Intensiva. 2014;26(2):89-121 e 26(3):215-39.

4. Schettino G, Cardoso LF, Mattar Júnior J, Ganem F. Critical patient: diagnosis and treatment. Hospital Sírio Libanês. $2^{\mathrm{a}}$ ed. Barueri (SP): Manole; 2012.

5. Azevedo LC, Park M, Salluh JI, Rea-Neto A, Souza-Dantas VC, Varaschin P, Oliveira MC, Tierno PF, dal-Pizzol F, Silva UV, Knibel M, Nassar AP Jr, Alves RA, Ferreira JC, Teixeira C, Rezende V, Martinez A, Luciano PM, Schettino G, Soares M; ERICC (Epidemiology of Respiratory Insufficiency in Critical Care) investigators. Clinical outcomes of patients requiring ventilatory support in Brazilian intensive care units: a multicenter, prospective, cohort study. Crit Care. 2013;17(2):R63.

6. Lai CC, Chen CM, Chiang SR, Liu WL, Weng SF, Sung MI, Hsing SC, Cheng KC. Establishing predictors for successfully planned endotracheal extubation. Medicine (Baltimore). 2016;95(41):e4852.

7. Behrendt CE. Acute respiratory failure in the United States: incidence and 31-day survival. Chest. $2000 ; 118(4): 1100-5$.

8. Silva DV, Ximenes GC, Silva Junior JM, Isola AM, Rezende $\mathrm{E}$. Aged patients with respiratory dysfunction: epidemiological profile and mortality risk factors. Rev Bras Ter Intensiva. 2009;21(3):262-8.

9. Zapata L, Vera P, Roglan A, Gich I, Ordonez-Llanos J, Betbesé AJ. B-type natriuretic peptides for prediction and diagnosis of weaning failure from cardiac origin. Intensive Care Med. 2011;37(3):477-85.

10. Mekontso-Dessap A, Roche-Campo F, Kouatchet A, Tomicic V, Beduneau G, Sonneville R, Cabello B, Jaber S, Azoulay E, Castanares-Zapatero D, Devaquet J, Lellouche F, Katsahian S, Brochard L. Natriuretic peptide-driven fluid management during ventilator weaning: a randomized controlled trial. Am J Respir Crit Care Med. 2012:186(12):1256-63.

11. Ma G, Liao W, Qiu J, Su Q, Fang Y, Gu B. N-terminal prohormone $\mathrm{B}$-type natriureytic peptide and weaning outcome in postoperative patients with pulmonary complications. J Int Med Res. 2013;41(5):1612-21.

12. Knaus WA, Draper EA, Wagner DP, Zimmerman JE. APACHE II: a severity of disease classification system. Crit Care Med. 1985;13(10):818-29.

13. Le Gall JR, Lemeshow S, Saulnier F. A new Simplified Acute Physiology Score (SAPS II) based on a European/North American multicenter study. JAMA. 1993;270(24):295763. Erratum in: JAMA 1994;271(17):1321.

14. Vincent JL, Moreno R, Takala J, Willatts S, De Mendonça A, Bruining H, Reinhart CK, Suter PM, Thijs LG. The SOFA (Sepsis-related Organ Failure Assessment) score to describe organ dysfunction/failure. On behalf of the Working Group on Sepsis-Related Problems of the European Society of Intensive Care Medicine. Intensive Care Med. 1996;22(7):707-10 
15. MP04JUL2013G. RMS: 10055311134. Brazil_add_ marketing@abbott.com.

16. Moraes RS, Fonseca JML, di Leoni CBR. ICU Mortality, associated factors and funtional status after discharge. Rev Bras Ter Intensa, 2005;17(2):80-4.

17. El-Fakhouri S, Carrasco HVCG, Araújo GC, Frini ICM. Epidemiological profile of ICU patients at Faculdade de Medicina de Marília. Rev Assoc Med Bras. 2016; 62(3):248-54.

18. Loss SH, Oliveira RP, Maccari JG, Savi A, Boniatti MM, Hetze MP, Dallegrave DM, Balzano PC, Oliveira ES, Höher JA, Torelly AP, Teixeira C. The reality of patients requiring prolonged mechanical ventilation: a multicenter study. Rev Bras Ter Intens. 2015;27(1):26-35.

19. Franca $S A$, Toufen $C$ Jr, Hovnanian $A L$, Albuquerque $A L$, Borges ER, Pizzo VR, Carvalho CR. The epidemiology of acute respiratory failure in hospitalized patients: a Brazilian prospective cohoort study. J Crit Care 2011; 26(3):330.e1-8.

20. Farghaly S, Galal M, Hasan AA, Nafady A. Brain natriuretic peptide as a predictor of weaning from mechanical ventilation in patients with respiratory illness. Australian Critical Care. 2015; 28:116.

21. Maraghi SE, Hosny M, Samir M, Radwan W. Usage of $B$-type natriuretic peptide for predictionof weaning outcome by spontaneous breathing trial. Egyptian Journal of Chest Diseases and Tuberculosis. 2014; 63:671-678.

22. Konomi I, Tasoulis A, Kaltsi I, Karatzanos E, Vasileiadis I, Temperikidis P, Nanas S, Routsi CI. Left ventricular diastolic dysfunction-an independent risk factor for weaning failure from mechanical ventilation. Anaesth Intensive Care. 2016; 44:466-73.
23. Menon N, Joffe AM, Deem S, Yanez ND, Grabinsky A, Dagal AHC, Daniel S, Treggiari MM. Occurrence and complications of tracheal reintubation in critically ill adults. Respir Care. 2012;57(10):1555-63.

24. Freitas EE, David CM. Assessment of success in weaning from mechanical ventilation. Rev Bras Ter Intensiva. 2006;18(4):351-9.

25. Zapata L, Vera P, Roglan A, Gich I, Ordonez-Llanos J, Betbese AJ. B-type natriuretic peptides for prediction and diagnosis of weaning failure from cardiac origin. Intensive Care Med. 2011;37(3):477-85.

26. Antonio AC, Teixeira C, Castro PS, Savi A, Oliveira RP, Gazzana MB, Knorst M. 48-Hour Fluid Balance Does Not Predict a Successful Spontaneous Breathing Trial. Respir Care. 2015;60(8):1091-6.

27. Deschamp J, Andersen SK, Webber J, Featherstone R, Sebastianski M, Vandermeer B, Senaratne J, Bagshaw $\mathrm{SM}$. Brain natriuretic peptide to pedict successful liberation from mechanbical ventilation in critically ill patients: a systematic review and meta-analysis. Critical Care (2020) 24:213

28. Mekontso-Dessap A, de Prost N, Girou E, Braconnier F, Lemaire $F$, Brun-Buisson C, Brochard L. B-type natriuretic peptide and weaning from mechanical ventilation. Intensive Care Med. 2006;32(10):1529-36.

29. Chien JY, Lin MS, Huang YC, Chien YF, Yu CJ, Yang PC. Changes in B-type natriuretic peptide improve weaning outcome predicted by spontaneous breathing trial, Crit. Care Med. 2008; 36:1421-1426.

Corresponding Author:

Dra. Maria Aparecida Vitagliano Martins

maria.vitagliano@hotmail.com

Editor:

Prof. Dr. Felipe Villela Gomes

Received in: sep 02, 2020

Approved in: feb 10, 2021 